Analysis of the difference in Imaging Mass Spectrometry Data characterized by Shannon entropy

Noritaka Masaki, Mitsutoshi Setou (Dept. Cell Biol. \& Anatomy, Hamamatsu Univ. Sch. Med.)

Through studies using Imaging Mass Spectrometry (IMS), we could successfully reveal key molecules and their distributions in various biological phenomena and diseases. On the other hand, we also found that these molecules usually behave not independently but relating to other molecules. To characterize the difference of IMS data taking account such interactions, we introduced Shannon entropy to overview mass spectra varied from position-to-position. In our previous presentation in this biophysical society, we discussed characteristic spatial distribution of Shannon entropy in mouse brain irrespective to anatomical representation. In this study, we will present which types of signals are dominant in Shannon entropy estimation and how they contribute to its variation.

$1 \mathrm{P} 297$

\section{生細胞における膜タンパク質標識法と会合状態解析法の開発 \\ Development of methods for labeling and oligomerization analysis of membrane proteins in live cells}

Yoshiaki Yano, Kenichi Kawano, Kaoru Omae, Sayaka Mtsuzaki, Katsum Matsuzaki (Grad. Sch. Pharm. Sci., Kyoto Univ.)

We have developed a specific labeling method for live-cell fluorescence imaging of membrane proteins using a high-affinity coiled-coil peptide pair to overcome limitations of conventional methods. Taking advantages of cell-surface-specific labeling and easiness in multicolor labeling, the oligomeric states of membrane proteins were precisely determined by spectral imaging FRET. We found that the $\beta 2$ adrenoceptor does not form constitutive homooligomers, and homooligomerizaiton is not necessary for their function. Furthermore, the influenza A M2 protein, which is proposed to form a tetrameric proton channel, was found to form a functional dimer at neutral $\mathrm{pH}$. Thus, this cell-based method is powerful for analysis of oligomerization of various membrane proteins.

\section{光干渉法を用いた細胞-ハイドロゲル間接着の定量評価}

Quantitative evaluation of cell adhesion to hydrogels by advanced interferometric optical microscopy

Takahisa Matsuzaki ${ }^{1}$, Gen Sazaki ${ }^{2}$, Masami Suganuma ${ }^{3}$, Tatsuro Watanabe ${ }^{3}$, Takashi Yamazaki ${ }^{1}$, Yuko Shimokawa ${ }^{1}$, Motomu Tanaka $^{4}$, Seiichiro Nakabayashi ${ }^{1}$, Hiroshi Yoshikawa ${ }^{1}{ }^{1}$ Grad. Sch. Sci \& Eng., Univ. Saitama, ${ }^{2}$ Inst. Low Temp. Sci., Univ. Hokkaido, ${ }^{3}$ Res. Inst. Clin. Onc., Saitama Cancer Center, ${ }^{4}$ Inst. Phys. Chem., Univ. Heidelberg)

Hydrogels are important tissue engineering scaffolds and ideal materials to direct cell function by serving key functionalities (e.g., mechanics) of native extracellular matrix. However, the imaging of physical contacts between cells and hydrogels with a nanometer resolution along the optical axis remain challenging because of low reflectivity of cell/hydrogel interfaces. In this work, to visualize cell/hydrogel interfaces, we have developed an interferometric optical microscopy combined with highthroughput optics, a confocal system, and a new class of monochromatic light source. By using the microscopy, we succeeded in evaluating the dependence of cancer cell spreading on hydrogel stiffness in a quantitative manner.
X-ray excited optical luminescence via bio-molecule directed metal clusters

Yasuko Osakada ${ }^{1,2}$, Yoshie Harada ${ }^{1}\left({ }^{1}\right.$ Kyoto university, iCeMS, ${ }^{2} J S T$ PRESTO)

Understanding the nature of X-ray excited optical luminescence is not only of fundamental interest but would also be meaningful for the development of novel computed tomography (CT) imaging. In this study, we, for the first time, investigated the X-ray excited optical luminescence from biomolecule directed metal clusters. Interestingly, the emission was only observed via metal clusters directed with bovine serum albumin, whereas neither lysozyme protein metal cluster nor DNA-directed cluster does not induce significant emission upon X-ray irradiation. These results provide new insight of metal clusters into the development of novel CT imaging probes.
$1 \mathrm{P} 298$

\section{走査型電気化学-イオンコンダクタンス顕微鏡を用いた神経 伝達物質の放出サイトのマッピング}

Mapping of neurotransmitter releasing sites using scanning electrochemical ion conductance microscopy

Yasufumi Takahashi ${ }^{1}$, Xiongwe Wang $^{2}$, Kosuke $\mathrm{Ino}^{2}$, Hitoshi Shiku ${ }^{2}$ Tomoakazu Matsue ${ }^{1,2}$ ( ${ }^{1}$ WPI-AIMR, Tohoku Univ., ${ }^{2}$ Enviromental studies, Tohoku Univ.)

Neurotransmitters are the chemical medium through which the signals move from one neuron to the next at the synapses. One technique with the potential to map chemically specific fluxes on the nanoscale is scanning electrochemical microscopy (SECM), but a lack of reliable distance control and difficulties in fabricating small-scale electrodes have largely restricted the technique to the microscale. We introduce an extremely quick and simple process with a high success rate for making double-barrel carbon nanoprobes for use in SECM-scanning ion conductance microscopy (SICM). The overall probe radius is controllable on the nano- to microscale, and the probes can be used for simultaneous chemical and topographical imaging.

\section{P301}

\section{成長円錐における単一分子レベルでのアクチン関連 mRNA の局在}

The localization of actin-related mRNAs in growth cone at a single molecule level

Hidenori Koizumi ${ }^{2}$, Yasuko Osakada ${ }^{1}$, Yoshie Harada ${ }^{1}$ ( ${ }^{1}$ iCeMS.,Univ. Kyoto, ${ }^{2}$ Grad.Sch.Bio., Univ. Kyoto)

In neurons, axon terminal is called "growth cone" which is ameba-like motile structure. At growth cone, the polymerization of actin-filaments is one of the most important factors for nerve growth and maintenance. However, how actin-related mRNAs function at axon terminal is not fully understood.

Therefore, we are investigating the dynamics and localization of actinrelated mRNAs at growth cone. In this study, we designed new visualization system to image actin-related mRNAs at single molecule level. Here, we plan to talk about our preliminary results observed at the growth cone of PC12 cells. 